"wore Christ-like than ever. And Christ will be inore constantly among us."

"And what will you be?" Ratiche asked.

"A Director of Constantly Changing Ceremonies and a keeper of the Relativity of Religion."

"Will the population be ordered in the sane way--spread out--individuals isolated for better self-understanding and growth?"

"Yes. The development will be unbelievable, the creativity godlike. Psychic thoughts will thrill flesh and soul like the greatest music. People will move bodily from point to distant point pirely by exercising their wills."

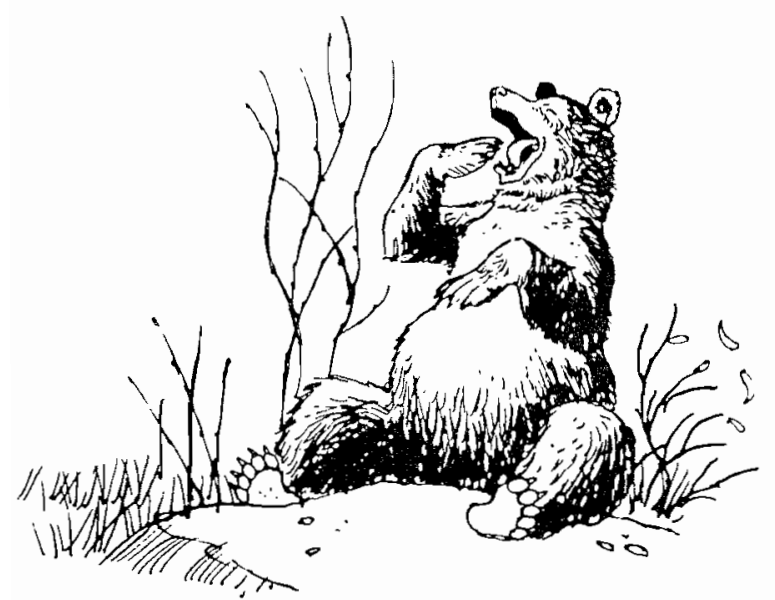

The figure faded.

I felt a strange weakness in ny limbs. Glancing at Grayson, I saw that he had finally been affected by the evidence. He was pale, frowning, gazing at the yround. The arrogant superiority had vanished.

Roonif took me aside.

"I have also been in touch with the future for your sake, Doan. I have been sensitive about your fate, have always admired you, and I knew when the trouble with Agra began."

My heart sickened, shrivelled. I trembled.

"Be of good cheer," Roonif whispered, gripping my arm. "I see in the future that you will conquer Ander and the whole horrible predicament. You will win Agra back. Youx

BETWEEN THE SPECIES love will be even more glorious."

I felt relief, joy, a rush of gratitude.

"Thanks to God!" I murrnured. "And to you, too, Roonif, for telling me."

And I closed my eyes and fixed Christ's image in my mind and praised it with ny whole being, tieccely and devoutly.

As we turned toward the hernitage, Rounif paused, held me back, and gazed into my eyes with quiet searching and enoouragement.

"Try to remember something else: you were married to Agra in a former existence."

"Married to her!"

"Yes. In Egypt. You were both refugees from the Atlantis community before it sank under the sea. Now again you have sought each other out by selecting mothers in this century and time, in order that you may test yourselves once again, overoome faults you could not correct earlier. God grant you the grace--and the character--to discem what the chief challenges are and to meet them victoriously."

I bowed my head.

"Challenges," I mused. "Eaults. I have to reflect and discover them."

(Tw be continued in the next issue)

Tall and slender, full of grace Noble Being of a noble race, Thy beauty, bird, is deep and sure Thy loveliness is soft and pure.

Thy shyness tells, to those who see, of tender sensitivity

Thy shyness, bird, cocoons thy soul To keep it soft, alive, and whole.

Thy gentleness brings shame to me For my dull'd sensibility.

Thy gentleness restoreth me To all that I was meant to be.

\section{DON CHRISTIANSON}

